KAREN RADNER ${ }^{1}$

\title{
The Stele of Adad-nērārī III and Nergal-ēreš from Dūr-Katlimmu (Tell Šaih Hamad)
}

\begin{abstract}
A Neo-Assyrian royal stele from Dūr-Katlimmu, modern Tell Šaih Hamad in Syria, bears two cuneiform inscriptions, one in the name of Adad-nērārī III of Assyria (r. 810-783 BC), the other in the name of Nergal-ēreš, governor of the Assyrian province of Rașappa. Both inscriptions concern the god Salmānu and his temple at Dūr-Katlimmu for whose reconstruction and refurbishment Adad-nērārī and Nergalēreš take credit.
\end{abstract}

Keywords: Assyria, $8^{\text {th }}$ century BC, Adad-nērārī III (king), Nergal-ēreš (official), Dūr-Katlimmu (city), Neo-Assyrian inscription, Neo-Assyrian stele, Salmānu (god), temple.

This paper presents a copy and an edition of a stele of Adad-nērārī III, king of Assyria (r. 810-783 BC), which Nergal-ēreš (or Pālil-ēreš), ${ }^{2}$ his governor in the province Rașappa, dedicated to the god Salmānu of Dūr-Katlimmu, modern Tell Šaih Hamad on the Lower Hābur in Syria. The presentation of the stele is based on examination of its two fragments, one in the British Museum and one in a private collection in Geneva. The stele, made of black basalt, is of the typical Assyrian shape with the rounded top and shows the king in prayer, surrounded by divine symbols. The monument bears two inscriptions, one on the front written from the point of view of the king and a second on the left hand side of the stele from the point of view of Nergal-ēreš, whose name and titles, like on the stele from

1 My thanks are due to Jonathan Taylor, British Museum, and the owner of the Geneva fragment, who wishes to remain anonymous, for allowing me to work with the stele fragments in their care, as well as to Frans van Koppen for his comments and suggestions. I am also grateful to John M. Russell, who first alerted me to the existence of the Geneva fragment, and to Hartmut Kühne, with whom I have discussed the Dūr-Katlimmu stele on several occasions, often in Tell Šaih Hamad itself. This paper was written as part of the research project 'Mechanisms of communication in an ancient empire: the correspondence between the king of Assyria and his magnates in the $8^{\text {th }}$ century BC', funded by the UK Arts and Humanities Research Council from 2008 to 2013. Bibliographical abbreviations used can be found in Reallexikon der Assyriologie und Vorderasiatischen Archäologie (R1A).

2 How the first element of the name, conventionally read Nergal-ēreš, or alternatively Pālil-ēreš, was pronounced is entirely unclear. There are good arguments for the assumption that neither Nergal nor Pālil is the correct reading. See discussion in Kühne / Radner (2008:31-32). 
Tell al-Rimah (see below), were erased at a later point. The inscriptions explicitly mention Dūr-Katlimmu as the seat of the god Salmānu, confirming the testimony of archival texts found at Tell Šaih Hamad (Radner 1998; 2002: 15-16). Adad-nērārī is credited with restoring the temple, while Nergal-ēreš, who is presented as a loyal supporter of the crown, is credited with dedicating on behalf of his king a golden sword and this very stele, so that the god might bless the ruler, his rule and his realm.

\section{The Two Fragments}

In May 1879, Hormuzd Rassam visited Tell Šaih Ḥamad 'for the purpose of examining an Assyrian sculpture, which was reported to me by different Arab travellers to exist there' (Rassam 1897: 311). This turned out to be a fragment from the top of a basalt stele with a cuneiform inscription and a representation of an Assyrian king in prayer, with only the head and an arm as well as three divine symbols preserved. The fragment 'had been hurled down the mound by the Arabs, who erected a shrine ..., as the effigy was considered an idol of the benighted heathens unfit to remain in that hallowed ground', but it was 'believed that the remainder of the [stele] is buried on top of the mound' (Rassam 1897: 312). Rassam confiscated the stele fragment and 'had great difficulty to move to the sea-coast what remained of the Assyrian sculpture, because it was too large to carry on horseback; and when we came to thin it, as I had taken some tools with me for the purpose, it was found too hard to cut' (Rassam 1897:312). While this may give the impression that Rassam was unable to cut away the stele's back, the fragment as it eventually arrived at the British Museum (inventory number: BM 131124) had been mutilated and is now only $15 \mathrm{~cm}$ thick. It has a maximum preserved height of $81 \mathrm{~cm}$ and a maximum width of $52 \mathrm{~cm}$. This upper fragment was identified as a stele of Adad-nērārī III by Alan Millard and Hayim Tadmor, who published a full edition with copy and photograph (1973).

While at Tell Šaih Hamad in 1879, Rassam had some test trenches dug (see Kühne 2008: 544) and intended to return the following year in order to search for the rest of the monument, but he did not receive the necessary permit (Rassam 1897: 313), and, to the best of our knowledge, he never returned to Tell Šaih Hamad. No further fragments of the stele have been unearthed during the German excavations conducted under the direction of Hartmut Kühne since 1978. At some point after Rassam's visit, a second, larger fragment of the same stele must have been discovered at the site, though when and how this occurred is presently unknown. This new fragment first came to public notice when it was offered for auction at Christie's in New York in 2000. Its connection with Rassam's piece was not recognized at the time, presumably as it was mistakenly attributed to Šamšî-Adad V of Assyria (Christie's New York, 13 June 2000: 134-135 no. 491). However, since the auction catalogue contained very good colour photographs of the front of the stele and its left hand side, which bears a second inscription, it was possible to propose the join with Rassam's piece from Tell Šaih Hamad and offer a reconstruction of its historical context (Radner 2002: 15; also Radner 2008: 543; Kühne / Radner 2008: 33-34). The piece was not sold at the time and was returned to Geneva, where it has since been stored in its shipping crate. In summer 2012, the owner of the fragment contacted Dr. Jon Taylor of the British Museum, 


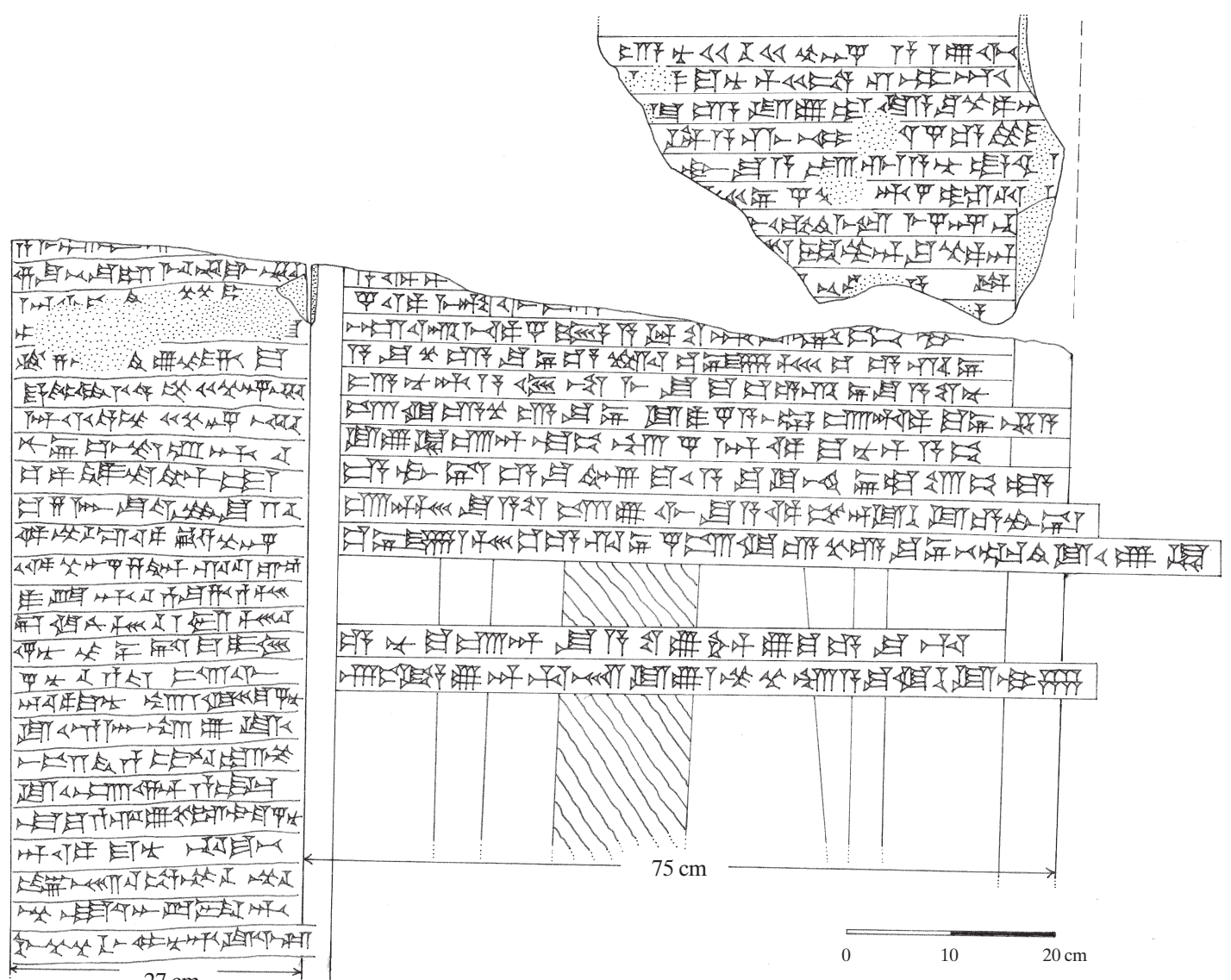

Fig. 1

and it was arranged for me to view it. I am pleased to be able to present here a full edition of the two inscriptions on the basis of my examination of the Geneva piece on 1 November 2012 and the British Museum piece on 16 November 2012. My copy (Fig. 1) combines both fragments. The British Museum fragment had previously been copied by Alan Millard (Millard / Tadmor 1973: pl. XXIX), and my copy differs only in line 9, which is somewhat better preserved and clearer to read than the earlier copy suggests.

The Geneva fragment preserves the stele's original width of $75 \mathrm{~cm}$ and its original thickness of $27 \mathrm{~cm}$. It is broken off at a height of $137.5 \mathrm{~cm}$ (max.). The inscription on the front, parts of which are preserved on both fragments, allows the reconstruction of the relative position of the two pieces and therefore the original height of the monument, resulting in the following dimensions: $212 \times 75 \times 27 \mathrm{~cm}$ (Fig. 2). The Dür-Katlimmu stele is therefore significantly larger than another stele of Adad-nērārī III and Nergal-ēreš of the same shape, the Tell al-Rima stele (RIMA 3, A.0.104.7), which likewise shows the king in prayer surrounded by divine symbols and is made of grey 'Mosul marble' and measures $130 \times 69.3 \times$ 20.4 cm (Börker-Klähn 1982: 196 no. 164.). A third stele of Adad-nērārī III and Nergal- 


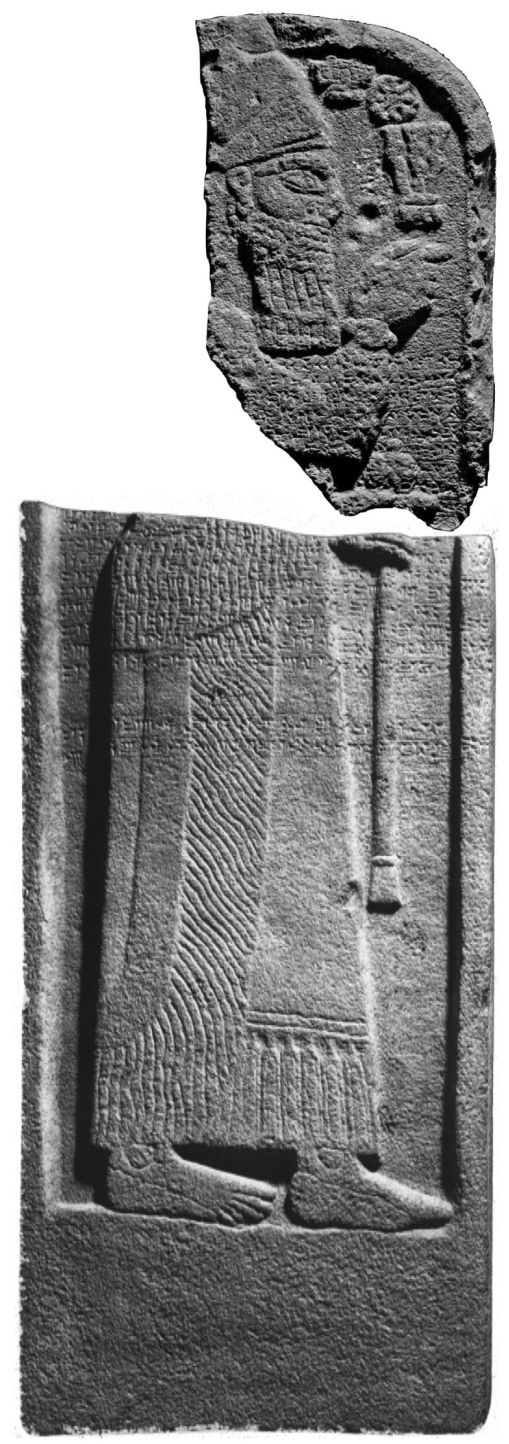

Fig. 2

ēreš, the Saba'a stele from the southern Jebel Sinjar, is likewise smaller at $192 \times 50 \times 38 \mathrm{~cm}$ (Börker-Klähn 1982: 196 no. 163), but looks rather different (see Blocher 2001:319, 322 for photographs). It also depicts the king in prayer amidst divine symbols, but is executed in such an unusual square shape that it may have served as an architectural element rather than a free-standing monument (RIMA 3, A.0.104.6). Adad-nērārī's Pazarcik (RIMA 3, A.0.104.3; $140 \times 44 \times 16.5 \mathrm{~cm}$; Donbaz 1990: 9) and Antakya stelae (RIMA 3, A.0.104.2; $127 \times 52 \times 31 \mathrm{~cm}$; Donbaz 1990: 7) were erected as border markers rather than dedicatory monuments and are of a different design altogether. 


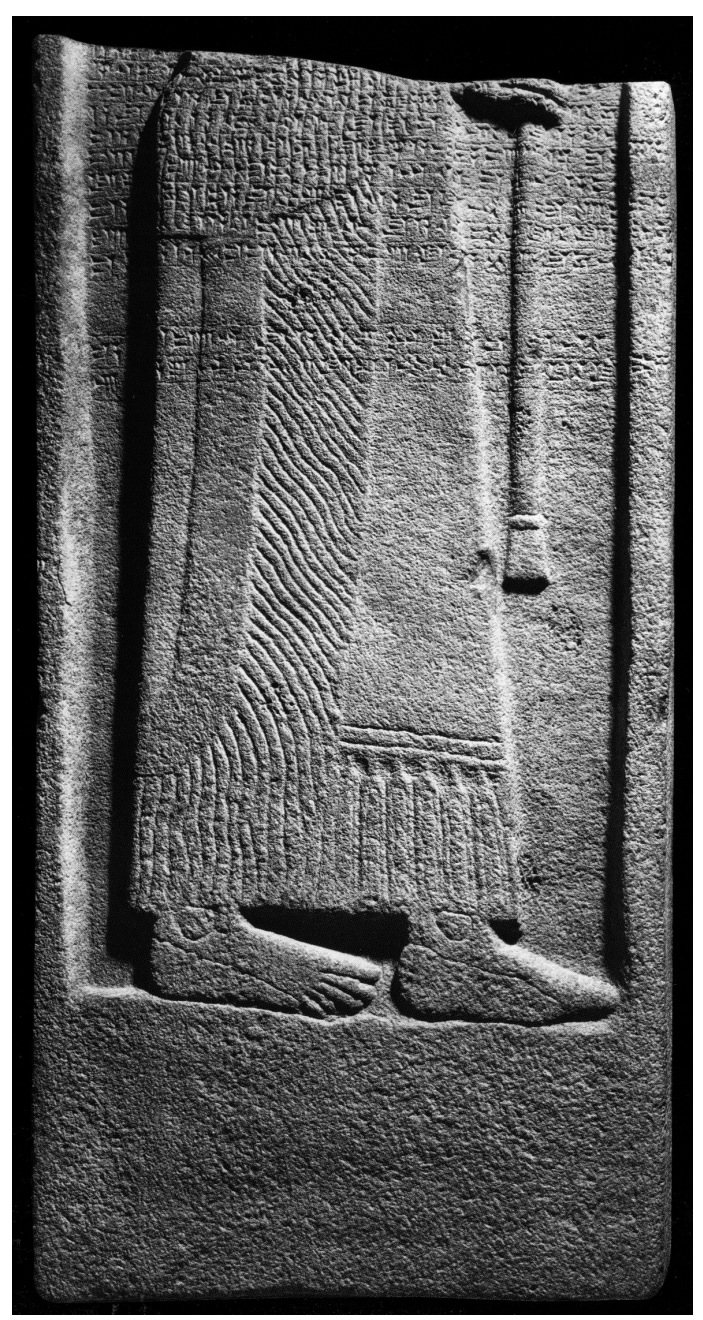

Fig. 3

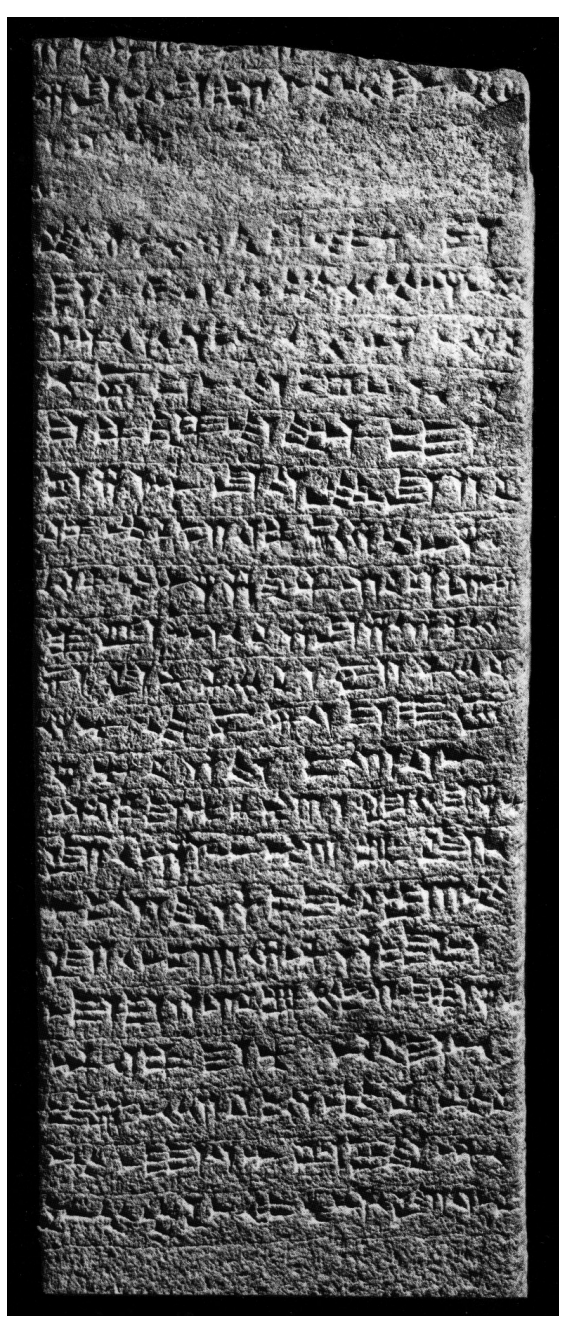

Fig. 4

The Geneva fragment weighs close to a ton, ${ }^{3}$ and whereas Tell Šaih Hamad today is no longer 'such an out-of-the-way place' as Rassam (1897: 313) found it to be, one must wonder how this heavy and unwieldy object might have been excavated and especially transported from the site. The German team that has worked annually at Tell Šaih Hamad since excavations began in 1978 never noticed illicit digging on the mound of the necessary large scale (Hartmut Kühne, pers. comm.), which may perhaps indicate that the stele had been unearthed before 1975, when Kühne and his collaborators first started surveying the site. This may perhaps lend some support to the assertion that the fragment 'was inherited from the owner's father in the 1960s' (Christie's New York, 13 June 2000: 134).

\footnotetext{
$3930 \mathrm{~kg}$ according to the note on its shipping crate.
} 


\section{The Inscription of Adad-nērārī III, King of Assyria}

On the front of the stele twenty lines of cuneiform inscription are incised across the body of the king, which is executed in high relief $(4 \mathrm{~cm})$. The fragment in the British Museum (BM 131124) preserves the ends of lines 1-10. The Geneva fragment, whose surface is better preserved than that of the other piece, has the beginnings of lines 9-10 and all of 11-20. The lines are separated by very straight horizontal rulings. The signs are well shaped and very regular despite the fact that they are incised across the body of the king. Several lines continue onto the raised, $5 \mathrm{~cm}$ wide border of the stele. In photographs, including the one presented here (Fig. 3), the shadows cast by the figure of the king and the rim obscure part of the text.

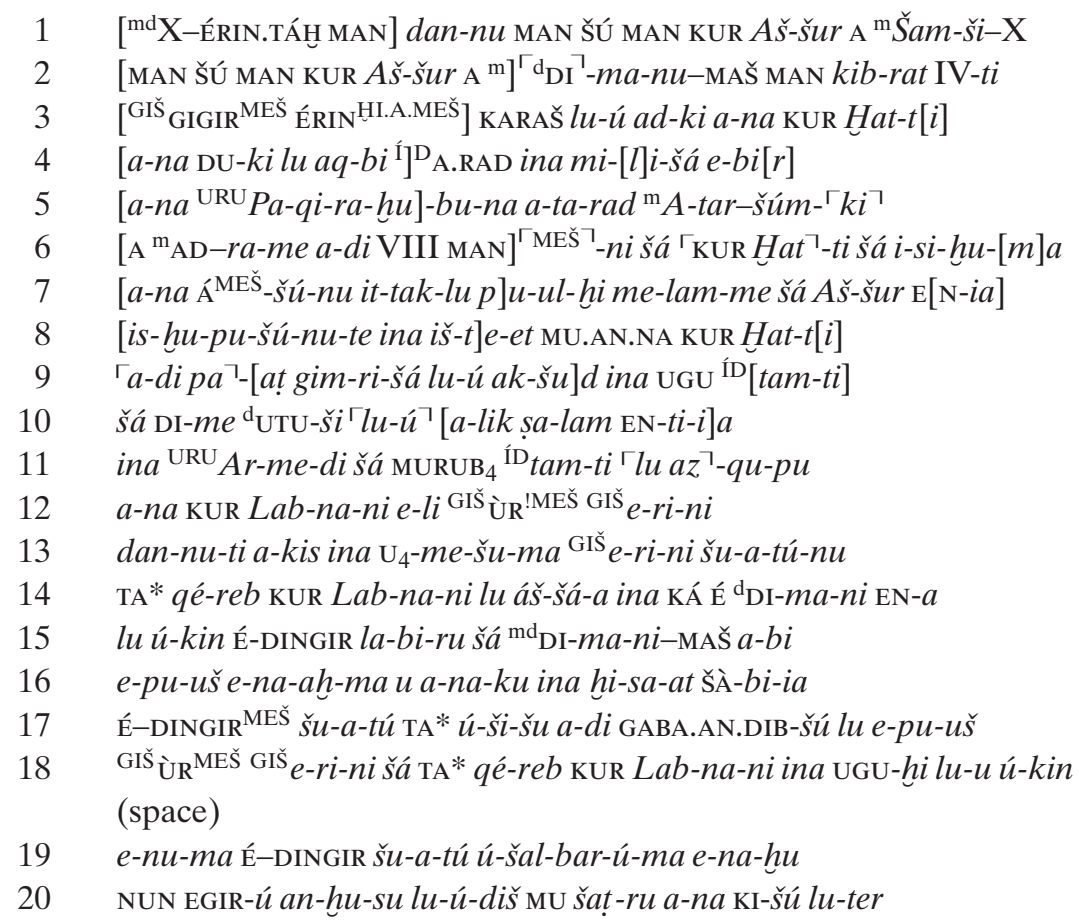

19 e-nu-ma É-DINGIR šu-a-tú ú-šal-bar-ú-ma e-na-ḩu

20 NUN EGIR-ú an-hูu-su lu-ú-diš MU šat -ru a-na KI-šú lu-ter

(1-2) [Adad-nērārī (III)], strong [king], king of the universe, king of Assyria, son of Šamš̄i-Adad (V), [king of the universe, king of Assyria, son of] Salmānu-ašarēd (= Shalmaneser III), king of the four quarters.

(3-4) I mustered (my) [chariotry, troops] and armed forces and [gave the order to march] to the land of Hatti. I crossed the Euphrates in flood. (5-6) I went down [to the city of Paqirahu]buna. Attār-šumkī, [son of Abī-rāme, together with eight kin]gs of Hatti, who had rebelled and (7-11) [trusted in their strength] - the awesome radiance of the god Aššur, my lord, [overwhelmed them. In just o]ne year, [I subdued] the land of Hatti to its full extent. Towards the s[ea] of the west [I marched]. I [erec]ted m[y lordly image] in the city of Arwad in the midst of the sea. (12-17) 
I ascended Mount Lebanon. I cut strong logs of cedar. At that time, I placed those cedars from Mount Lebanon in the gate of the temple of the god Salmānu, my lord. The old temple, which Salmānu-ašarēd (= Shalmaneser I), my ancestor (lit. father), had built, had become dilapidated and I, in a stroke of inspiration, built this temple from its foundations to its parapets. (18) I placed the cedar roof beams from Mount Lebanon on top.

(19-20) When this temple becomes old and dilapidated may a future prince renovate its dilapidated parts and return the inscription (lit. written name) to its place.

9: There is a space between the two components of the sign ÍD due to the fact that the carving of the fingers of the king precluded writing there.

11: URU Ar-me-di is the first such spelling of Arwad (see Bagg 2007: 27-29, s.v. Arwāda for the other attestations), but the identification with the island city is clear because of its description as ša qabal tâmti, 'in the midst of the sea', and the overall context. The Tell al-Rimah stele (RIMA 3, A.0.104.7:10) has URU Ar-ma-di.

12: The final vertical wedge of the sign ÜR is missing. - According to the Tell al-Rimah stele, Adad-nērārī cut 100 cedar beams 'for the requirements of my palace and temples' (RIMA 3, A.0.104.7:11). Constructing the Salmānu temple's gate and roof out of the Lebanese cedar beams must have consumed a significant portion of that number.

The inscription contains a version of the report of the campaign of $805 \mathrm{BC}$ against an alliance of western rulers under the leadership of Attār-šumkī of Arpad, which, after the defeat of the coalition at Paqirahubuna (in the region of modern Gaziantep in southeastern Turkey; see Bagg 2008: 186, s.v. Paqarhubuni), afforded an opportunity to visit the Mediterranean and the island of Arwad, off the shore of the modern city of Tartus in Syria. All this information is known already from other inscriptions issued in Adad-nērārī's name (Millard / Tadmor 1973: 57-64). New, and specifically relevant for Dūr-Katlimmu, is that a visit to Mount Lebanon at that time resulted in cedar logs being brought back in order to renovate the temple of Salmānu, the god of Dūr-Katlimmu. This shrine is said to be a foundation of 'my father Salmānu-ašarēd', which must refer to the first king of that name (r. 1263-1234 BC), who indeed has already been suggested as the temple's founder on independent grounds (Radner 1998:49-51).

\section{The Inscription of Nergal-ēreš, Governor of Raṣappa}

On the left side of the stele are preserved 25 further lines of the cuneiform inscription, with at least one line missing at the beginning (Fig. 4). The lines are separated by irregularly applied rulings. The signs are not as deeply incised as those on the front and are less evenly arranged. The sign forms are also less uniform, e.g., the sign MEŠ appears in two variants (compare $11.10^{\prime}$ and $18^{\prime}$ with $11.13^{\prime}$ and $14^{\prime}$ ). There are also some mistakes in lines $7^{\prime}$ and $11^{\prime}$ (see below). While it is easy to find fault with the work of the stone mason who applied the inscription, whoever composed the text made use of a highly literary language and 
vocabulary, which contrast with the blander inscription on the front. This literary style is reminiscent of that found in the inscriptions of Šamšīi-ilu, the field-marshal of Adad-nērārī III (see Dalley 2000: 85-86). There are some passages in our inscription that are so far without direct parallels (see below). Most of lines $3^{\prime}$ and $4^{\prime}$ were intentionally erased at a later point, largely obscuring the name and titles of Nergal-ēreš and damaging also some of the signs in line $5^{\prime}$.

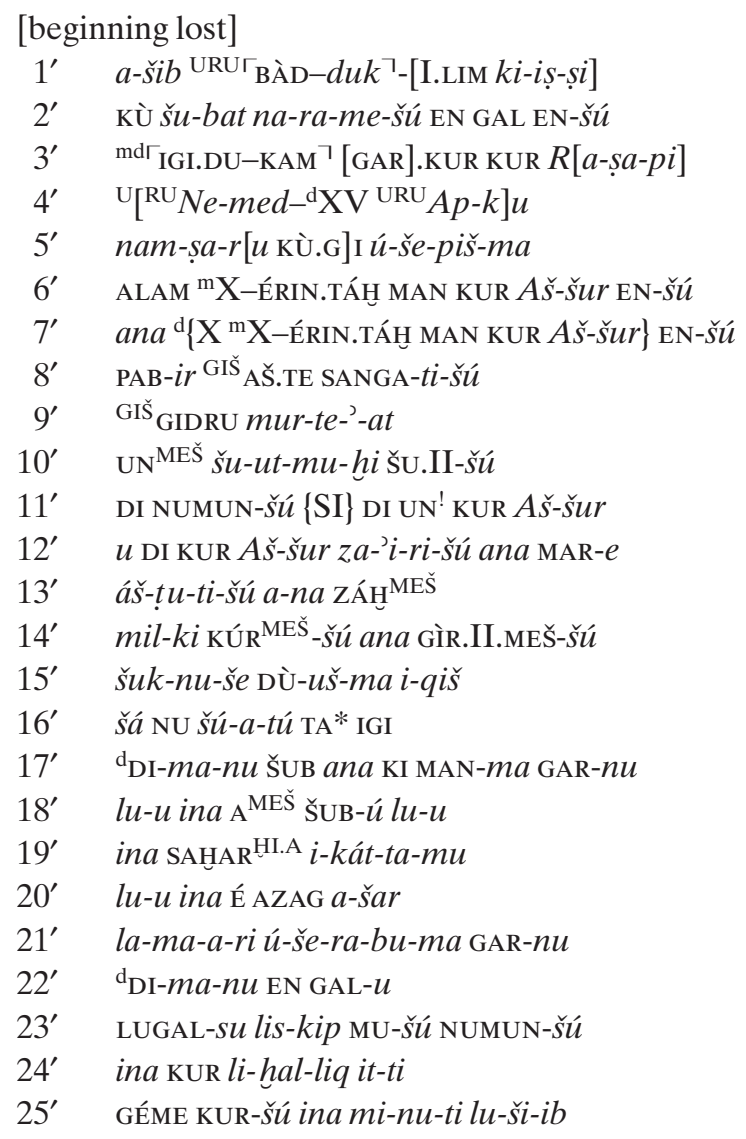

[To the god Salmānu] $\left(1^{\prime}-2^{\prime}\right)$ who resides in Dūr-Kat[limmu, the] holy [shrine], his beloved abode, the great lord, his lord.

$\left(3^{\prime}-4^{\prime}\right)$ Nergal-ēreš, [gover] nor of the country of R[aṣappa], the city of [Nēmed-Issar (and) the city of Apk]u, (5') had a gol[den sw]ord made and (15') made and presented $\left(6^{\prime}-8^{\prime}\right)$ an image of Adad-nērārī III, king of Assyria, his lord, to the god Salmānu!! \{Text: Adad Adad-nērārī, king of Assyria\}, his lord, who protects the throne of his priesthood, $\left(9^{\prime}-15^{\prime}\right)$ to give into his hands the sceptre that shepherds the people, for the wellbeing of his seed, the wellbeing of the people of Assyria and the wellbeing of Assyria, to scatter his adversaries, to destroy his fierce foes, to subdue his enemy princes. 
(16-21) Whoever discards this image from the presence of Salmānu (or) puts it into another place, whether he throws it into water or covers it with earth or brings and places (it) into a taboo house where it is inaccessible, (22-25) may the god Salmānu, the great lord, overthrow his sovereignty; may his name (and) his seed disappear in the land; may he live in a contingent together with the slave women of his land.

5': In Neo-Assyrian usage, a namșaru-sword is no ordinary blade but a weapon fit for a god (see CAD N/1 246, s.v. namșaru). Sargon II's Letter to Aššur contains a description of the golden namșaru that Haldi of Mușașir 'wore at his side' (TCL 3,377 ), and the object presented here by Nergal-ēreš will have been a similar weapon for Salmānu.

7': The passage marked with \{\} is an obvious copying mistake, where the stone mason repeated parts of the previous line. We can correct this passage with confidence to read Salmānu, as it is this deity that is referenced in lines $17^{\prime}$ and $22^{\prime}$ and of course also in the inscription on the front of the stele.

8'-9': Salmānu is presented as the guardian of kingship, as the protector of the throne and the donor of the sceptre. This is the first explicit such mention attested for the first millennium, but it fits well with the fact that Salmānu is one of the 'gods of the palace' receiving votive gifts as part of the installation of the new king according to the so-called Middle Assyrian Coronation Ritual (see Radner 1998:39).

9'-10': hatț murtê'at nišê, 'the sceptre that shepherds the people' is attested in an inscription of Adad-nērārī II (911-891 BC): RIMA 2, A.0.99.2: 7-8.

11': Again there are some writing mistakes. The sign SI seems to be superfluous and the sign interpreted here as UN has too many vertical wedges.

$12^{\prime}-14^{\prime}$ : No fewer than three synonyms are used to describe the king's enemies, the frequently used terms $z \bar{a}^{3} i r u$ and nakru as well as the rather more high-brow aštūte, which is attested in Assyrian inscriptions from Tukultī-apil-Ešarra (= Tiglath-pileser) I (1114-1076 BC) onwards (CAD A/II 475, s.v. ašṭ a.2'). Roughly contemporary to our reference is a passage in an inscription of Šamšīilu, Adad-nērārī III's field-marshal, from Til-Barsip that calls the goddess Ištar sākipat aštūte, 'she who drives out the fierce foes' (RIMA 3, A.0.104.2010: 7). $z \vec{a}$ ir $\bar{\imath} \bar{s} u$ ana zarê, 'in order to scatter (like seed) his adversaries': there seem to be no parallels so far for the use of zarû, 'to sow seed, to scatter' (CAD Z, 70-71), in other Assyrian inscriptions, although the alliteration with $z \vec{a} i r u$ makes this a particularly attractive turn of phrase.

16'-17': At Tell al-Rimah, Nergal-ēreš's stele was found in situ inside the cella of the temple beside the podium that once held the statue of the god, apparently seated on a throne (Oates 1968: 123, pl. XXXII-XXXIII; Page 1968: 139). We can assume that the Dūr-Katlimmu stele was set up in a similar position inside the Salmānu temple.

25': The last curse formula has no known parallels in the corpus of Assyrian inscriptions. The rest of the curse section, especially the description as to what evil fate might be in store for the monument (see Radner 2005: 259), runs largely parallel 
to the formulation of the Saba'a stele (RIMA 3, A.0.104.6: 26-30), although there Aššur and Marduk, rather than Salmānu, are the ones who are to punish any offender.

\section{The Date of the Monument}

The stele is dated to the reign of Adad-nērārī III (810-783 BC). The titles of Nergal-ēreš, albeit mostly erased, nevertheless allow us to narrow this down to the period prior to 797 BC. Two of his holdings can be reconstructed with relative certainty as Rașappa and Apku. The latter city is associated with Nēmed-Issar in the Saba'a stele (RIMA 3, A.0.104.6), and the very concise title of Nergal-ēreš on a small stone cylinder reads 'governor of NēmedIssar and Rașappa’ (RIMA 3, A.0.104.2006), which makes Nēmed-Issar a plausible candidate for the second toponym in the present list (certainly a city). Nergal-ēreš does not appear to control Hindānu yet, which was added to his holdings by royal edict in 797 (RIMA 3, A.0.104.9). On the other hand, a direct link is made between the logging of cedar beams in the Lebanon, dated to 805 due to the connection with the campaign against Arpad, and the renovation of the Salmānu temple, for which the stele was fashioned. This suggests a dating of the monument to 805 or relatively soon thereafter, and certainly before 797 .

\section{Nergal-ēreš, Dūr-Katlimmu and Salmānu -A Special Relationship?}

Nergal-ēreš's holdings as a governor included the city of Dūr-Katlimmu, as is made explicit in the inscription of the Saba'a stele (RIMA 3, A.0.104.6:24). In the present inscription, we encounter Nergal-ēreš specifically as a devotee of the god Salmānu. One might simply assume that the care for Dūr-Katlimmu's patron deity Salmānu was part of his expected duties as the senior administrator of the province in which this temple was located. After all, Nergal-ēreš also dedicated, on behalf of Adad-nērārī, stelae for the storm god Adad at Zamāhu (Tell al-Rimaḥ) and at Saba'a. ${ }^{4}$

Or are there any indications for a special relationship? Indeed, the god Salmānu is also attested elsewhere in close association with Nergal-ēreš, and, significantly, this is the case at least two decades after his donation of sword and stele to Salmānu and, moreover, outside of Dūr-Katlimmu. The only Neo-Assyrian archival tablet so far excavated at Tell al-Rimah is a legal text dated to 777 BC. It documents how the governor Nergal-ēreš exchanged a field against one controlled by an official from Zamāhu (Tell al-Rimah), and this transaction is, as was the norm, protected with security clauses that curse whoever would break the contract. The first of these clauses is so far without parallel and reads, 'May the gods Salmānu and [DN] make him disappear from Nēmed-Issar!' (Postgate 1970:31-32, pl. XI:

${ }^{4}$ The ancient name of Saba'a is unclear, although the passage ina AN za-ban-ni ul-ziz-šú (RIMA 3, A.0.104.6: 22) would seem to refer to it. But Saba'a is certainly not Zabban, a notable cult centre of Adad, which, however, is a city in the Diyala region (George 2008). 
TR 4001 14-17). Unfortunately, the name of the second deity is damaged, and the remains of the signs as copied by Postgate cannot be restored in a way that would offer a convincing reading; but it is certainly not the name of Adad, the god to whom Nergal-êreš had dedicated the Tell al-Rima stele and whose mention would be far less surprising in the present context than that of Salmānu. This is, after all, one of the extremely rare NeoAssyrian attestations for the god Salmānu outside of Dūr-Katlimmu (see Radner 1998), the only place where the deity is well attested at the time. ${ }^{5}$ While it seems most likely that the god is mentioned here due to Nergal-ēreš's role in the text, it nevertheless remains unclear what underpins this relationship.

That we do not know what role the city of Dūr-Katlimmu played within Nergal-ēreš's holdings and Adad-nērārī's realm is of course part of the problem; but the fact remains that according to the inscription of our stele, the king, 'in a stroke of inspiration', decided to completely rebuild Dūr-Katlimmu's ancient temple at a time when the Assyrian presence in the Jezirah was revitalised at considerable expense (Kühne 2010:118-126). That he even used for this enterprise precious cedar beams from Lebanon, of which only 100 had been brought back from the campaign to the Mediterranean in 805 , suggests that the city and its temple were meant to play a prominent and very visible role within the imperial project.

Recent archaeological work at Tell Saih Hamad has highlighted the great potential for recovering evidence for the time of Nergal-ēreš. In 2003, an impression of the cylinder seal of one 'Išme-ilu, the eunuch of Nergal-ēreš' from a discarded jar sealing (Kühne / Radner 2008) was excavated in Tell Šaih Hamad's lower town, radically changing previous assumptions about the development of the city, whose lower town had been thought to be a much later creation. Now, however, it has emerged that Dūr-Katlimmu's transformation from a relatively small town to a 60 hectare city began already in the $9^{\text {th }}$ century BC, and the fact that the site underwent major changes during the time that Nergal-ēreš controlled it has started to become clear (Pucci 2010).

\section{The Deletion of Nergal-ēreš's Name and Titles}

Nergal-ēreš remained governor of Rașappa and his other holdings long after he dedicated the Dūr-Katlimmu stele and also after Adad-nērārī had been succeeded by his son Salmānu-ašarēd IV (r. 782-773 BC). He was in active service at the very least until 775 BC, as this was the year when he held the office of year eponym for the second time, after a first turn in 803 BC under Adad-nērārī (Millard 1994: 57-58). At some point thereafter, his name and titles were erased from the Dūr-Katlimmu stele. Our monument offers no clues as to when and why this happened.

Nergal-ēreš's name and titles were also deleted from the Tell al-Rimah stele, along with an entire section detailing how the king had authorized him to rebuild 331 settlements in the Jezirah (RIMA 3, A.0.104.7: 13-21; Page 1968: pl. XXXIX-XLI). As this forms the end of the inscription on the front of the stele, the deletion of these nine lines is far more

5 See Radner (2002: 262, s.v. Salmānu) and the personal names listed in Radner (2002: 250-251, s.v. Salmānu-...), with two more attestations from Dūr-Katlimmu in Radner (2010:183-184). 
noticeable than in the case of the Dūr-Katlimmu stele, where only two lines of the less prominent inscription on the left hand side were excised. In addition to the mutilation of the stele, the Adad temple of Zamāhu (Tell al-Rimah) also suffered the erasure of the inscriptions on two pairs of lion-head column bases (Oates 1968: pl. XXXVII) from the outer façade of the cella, which have been interpreted (Oates 1968: 125; Page 1968: 139-140), correctly in my view, as duplicates of the stele inscription. Despite the mutilation of their inscriptions, the stele and the column bases were left inside the temple, close to the divine statue. We may assume, therefore, that also the Dūr-Katlimmu stele remained inside the Salmānu temple.

While Nergal-ēreš's inscriptions in the temples of Zamāhu and Dūr-Katlimmu were defaced, other monuments of Nergal-ēreš elsewhere, such as the Saba'a stele and the stone tablet from the Ištar temple of Nineveh (RIMA 3, A.0.104.9), remained unharmed. Thus, whatever prompted the obliteration of Nergal-ēreš's name and titles in Zamāhu and Dūr-Katlimmu must have been of specific regional import and not necessarily relevant elsewhere; perhaps it points not to Nergal-ēreš's assumed personal downfall ${ }^{6}$ but is a result of the division of the province of Rașappa, which under Nergal-ēreš (Radner 2006: 52-53) included regions such as Lāqê and Hुindānu that were later turned into separate provinces. Dūr-Katlimmu, for one, was then part of the province of Lāqê (established at the latest by 736: Radner 2002: 4; 2006: 55), and once Nergal-ēreš's territories had been divided it may have been deemed inappropriate to advertise that the city and its temple had formerly been controlled by a governor of Rașappa.

\section{Bibliography}

Bagg, A. M. (2008): Die Orts- und Gewässernamen der neuassyrischen Zeit 1: Die Levante (RGTC 7/1), Tübingen.

Blocher, F. (2001): Assyrische Würdenträger und Gouverneure im 9. und 8. Jh. Eine Neubewertung ihrer Rolle, AoF 28, 298-324.

Börker-Klähn, J. (1982): Altvorderasiatische Bildstelen und vergleichbare Felsreliefs (BagM 4), Mainz.

Christie's New York, 13 June 2000. Antiquities Sale 9380. Catalogue. London.

Dalley, S. (2000): Shamshi-ilu, Language and Power in the Western Assyrian Empire. In: G. Bunnens (ed.), Essays on Syria in the Iron Age (ANES Suppl. 7), Louvain: 79-88.

Donbaz, V. (1990): Two Neo-Assyrian Stelae in the Antakya and Kahramanmaraş Museums. ARRIM 8, 5-24.

Fuchs, A. (2008): Der Turtān Šamšī-ilu und die große Zeit der assyrischen Großen (830-746), WO 38, 61-145.

George, A. (2008): The Sanctuary of Adad at Zabban? A Fragment of a Temple List in Three Subcolumns, BiOr. 65, 714-717.

Grayson, A.K. (1991): Assyrian Rulers of the Early First Millennium BC, I (1114-859 BC) (RIMA 2), Toronto.

6 Andreas Fuchs (2008: 94) has recently argued that he, together with the field-marshal Šamšī-ilu, found his death in the course of the usurpation of the Assyrian throne by Tukultī-apil-Ešarra (Tiglath-pileser) III in 745 and sees the mutilation of the inscriptions as key evidence for this assumption. But Nergalēreš may already have died long before these events as there are no known attestations available for the period after 775 . 
Grayson, A. K. (1996): Assyrian Rulers of the Early First Millennium BC, II (858-745 BC) (RIMA 3), Toronto.

Kühne, H. (2008): Šaih Hamad, Tall. B. Archäologisch. In: RlA 11, 543-551.

Kühne, H. (2010): The Rural Hinterland of Dur-Katlimmu. In: H. Kühne (ed.), Dur-Katlimmu 2008 and beyond (Studia Chaburensia 1), Wiesbaden, 115-128.

Kühne, H. / Radner, K. (2008): Das Siegel des Išme-ilu, Eunuch des Nergal-ēreš, aus Dūr-Katlimmu, ZA 98, 26-44.

Millard,A. (1993): The Eponyms of the Assyrian Empire, 910-612 BC (SAAS 2), Helsinki.

Millard, A. / H. Tadmor (1973): Adad-nirari III in Syria. Another Stele Fragment and the Dates of his Campaigns, Iraq 35, 57-64.

Oates, D. (1968): The Excavations at Tell al Rimah. 1967, Iraq 30,115-138.

Page, S. (1967): A Stele of Adad-nirari III and Nergal-ereš from Tell al Rimah, Iraq 30,139-153.

Postgate, J. N. (1970): A Neo-Assyrian Tablet from Tell al Rimah, Iraq 32, 31-35.

Pucci, M. (2010): The Discovery of the City-canal of Dur-Katlimmu. In: H. Kühne (ed.), Dūr-Katlimmu 2008 and Beyond (Studia Chaburensia 1), Wiesbaden, 163-174.

Radner, K. (1998): Der Gott Salmānu ("Šulmānu”) und seine Beziehung zur Stadt Dūr-Katlimmu, WO 29,33-51.

Radner, K. (2002): Die neuassyrischen Texte aus Tall Šēh Hamad (BATSH 6), Berlin.

Radner, K. (2005): Die Macht des Namens. Altorientalische Strategien zur Selbsterhaltung (SANTAG 8), Wiesbaden.

Radner, K. (2006): Provinz. C. Assyrien. In: RlA 11, 42-68.

Radner, K. (2008): Šaih Hamad, Tall (Dūr-Katlimmu). A. Philologisch. In: RlA 11, 543-551.

Radner, K. (2010): Neue neuassyrische Texte aus Dur-Katlimmu. Eine Schülertafel mit einer sumerischakkadischen Königshymne und andere Keilschriftfunde aus den Jahren 2003-2009. In: H. Kühne (ed.), Dur-Katlimmu 2008 and Beyond (Studia Chaburensia 1), Wiesbaden, 175-186.

Rassam, H. (1897): Asshur and the Land of Nimrod, being an account of the discoveries made in the ancient ruins of Nineveh, Asshur, Sepharvaim, Calah, Babylon, Borsippa, Cuthah, and Van, incl. a narrative of different journeys in Mesopotamia, Assyria, Asia Minor, and Koordistan, Cincinnati.

Thureau-Dangin, F. (1912): Une relation de la huitième campagne de Sargon (714 av. J.-C.) (TCL 3), Paris.

Karen Radner

History Department

University College London

Gower Street, London WC1E 6BT

k.radner@ucl.ac.uk 